\title{
DWA OBLICZA ŻYCIA IMIGRANTÓW W ENKLAWIE ETNICZNEJ
}

Przedmiotem rozważań są skutki społeczne życia długotrwałych imigrantów w enklawach etnicznych, tzn. osób, które zamierzaja osiąść na stałe lub przynajmniej na długi czas w kraju przyjmującym oraz ich potomków. Wiele państw bowiem, również europejskich, staje się miejscem życia migrantów, w tym przybywających falami osób tej samej narodowości. Szczególnie interesujący jest tu ten rodzaj enklaw, który charakteryzuje się występowaniem obu wymiarów konstytuujących enklawę: społecznym, kładącym nacisk na jej odmienność od otoczenia, a równocześnie przestrzennym, stanowiącym obszar o odmiennym niż otoczenie charakterze ${ }^{1}$.

Enklawy etniczne tworzą się i umacniają w efekcie oddziaływania czynników wewnętrznych, czyli tych, które charakteryzują społeczności imigrantów, oraz zewnętrznych, charakteryzujących kraje przyjmujące. Do uwarunkowań zewnętrznych należy zarówno oddziaływanie czynników wykluczających w społeczeństwie przyjmującym, praktyk dyskryminujących, niekorzystnego lub nieczytelnego dla przybyłych prawa, jak i gloryfikacja oraz umacnianie odmienności kulturowej ${ }^{2}$, „fetyszyzowanie różnicy” pomiędzy różnymi grupami etnicznymi zgodnie z doktryną multikulturalizmu lewicowo-liberalnego. Charakteryzując tę doktrynę, Wojciech Burszta podkreślał, że: „Jest to działanie na rzecz uwzględniania Inności jako podstawy kulturowej autentyczności i poszerzania przestrzeni społecznej dla jej swobodnej artykulacji”’. Ta forma przeradza się w „fetyszyzowanie różnicy” oraz hasła „separatyzmu politycznego i kulturalnego"4.

W tym opracowaniu omawiane są te enklawy, które powstają na skutek aktywności samych migrantów oraz uwarunkowań leżących przede wszystkim po stronie przybywającej społeczności.

${ }^{1}$ Por. R. Suchocka, Miejskie enklawy etniczne, w: L. Gołdyka, I. Machaj (red.), Enklawy życia społecznego. Kontynuacje, Wydawnictwo Naukowe Uniwersytetu Szczecińskiego, Szczecin 2009, s. 427 .

${ }^{2}$ Por. F. Fukuyama, Wielki Wstrzqs. Natura ludzka a odbudowa porzadku społecznego, Politeja, Warszawa 2010, s. 254.

${ }^{3}$ W. J. Burszta, Blaski i cienie multikulturalizmu, „Sprawy Narodowościowe”, Seria nowa, t. 5, 1996, z. 1 (8), s. 130.

${ }^{4}$ Ibidem, s. 131. 
Do czynników sprzyjających tworzeniu enklaw etnicznych należą przede wszystkim te, które wynikają z sytuacji migracyjnej i postaw osób zmieniajacych miejsce pobytu, a mianowicie:

a) zmiana wywołana nowymi warunkami i konieczność zaadaptowania się do nich, przystosowania się do życia w obcym kulturowo kraju, zwłaszcza w sytuacji braku znajomości języka, obowiązującego prawa, panujących obyczajów, poszukiwania pracy i mieszkania;

b) występowanie kolejnych fal migracji, migracja grup, a nie pojedynczych jednostek;

c) migracje łańcuchowe i występowanie sieci powiązań między osiadłymi a przybywajaccymi migrantami.

Życie w enklawie staje się panaceum na trapiące przybyłych lęki, jak: lęk przed nieznanym, lęk przed niemożnością sprostania sytuacji, która stała się wyzwaniem. Ułatwia walkę ze stresem spowodowanym rozłąką z rodziną i specyfiką pracy za granica, uwalnia od samotności i poczucia izolacji w obcym społeczeństwie. Jest ucieczką od niepewności i ryzyka do bezpieczeństwa wspólnoty, która zapewnia poczucie przynależności i społeczne więzi oraz wytwarza przekonanie, że można korzystać z jej wsparcia.

Często wspólne wyznanie i zaangażowanie religijne wzmacniają wewnętrzną integrację w enklawach tworzonych przez migrantów. Ma to szczególny wymiar, gdy migranci mają własny kościół i możliwość uczestnictwa we własnej kulturze religijnej. Podkreślając znaczenie i specyfikę duszpasterstwa emigrantów z Polski, Roman Dzwonkowski wskazuje na odmienność kultury religijnej społeczeństwa przyjmującego i dążenia do szybkiej asymilacji religijnej migrantów z Polski przez włączenie ich w duszpasterstwo w miejscowym języku . Parafia polska czy dojazdowy punkt duszpasterski „pozostaje najważniejszą społecznotwórczą instytucją polską na emigracji. Stwarza bowiem nieosiagalne dla innych instytucji możliwości skupienia emigrantów, wzajemnego poznania się ich i samopomocy oraz stanowi najważniejsze, religijne, moralne i kulturowe ich oparcie. Dzięki niej amorficzna zbiorowość

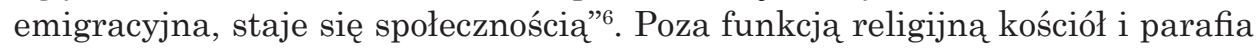
pełnią funkcje społeczne i humanitarne: oferują praktyczne wsparcie migrantom, pełnią funkcję informacyjna, prowadzą nauczanie języka polskiego dla dzieci. Szereg aspektów oddziaływania Kościoła w zakresie opieki udzielanej migrantom z Polski, w tym długotrwałym, został przedstawiony przez Jadwigę Plewko w pracy uwzględniającej różne okresy migracji z Polski, od migracji przed I wojną światową poczynajac do czasów współczesnych ${ }^{7}$. Autorka podkreślała, że opieka ta „zawsze miała wydźwięk społeczny i narodowy oraz wymiar praktycznego wsparcia w realnych sytuacjach życia i pracy za granica”.

${ }^{5}$ Por. R. Dzwonkowski SAC, Nowa emigracja - problemy duszpasterskie, w: G. Koszałka, J. Plewko, M. Stopikowska (red.), Nauki o rodzinie. Migracje Polaków po roku 2004 i ich konsekwencje dla rodziny. Studia i badania naukowe, Gdańsk 2009, r. III, nr 1, Wydawnictwo „Ateneum - Szkoła Wyższa” w Gdańsku, Gdańsk 2009, s. 40.

${ }^{6}$ Ibidem, s. 40-41.

7 J. Plewko, Sprostać migracji. Pomoc migrantom ekonomicznym z ziem polskich (połowa XIXpoczatek XXI wieku, Wydawnictwo KUL, Lublin 2010.

${ }^{8}$ Ibidem, s. 213. 
Integracyjna funkcja wspólnot religijnych umacnia wspólnoty etniczne. Sale modlitw i meczety, stowarzyszenia tworzone przez emigrantów z Maghrebu we Francji sprzyjają utrwalaniu poczucia odrębności kulturowej i etnicznej jej członków, prowadzą do etnicyzacji sfery religijnej i haseł powrotu do źródeł ${ }^{9}$.

Migracje, które miały charakter grupowy, niejako automatycznie wyzwalały współpracę $\mathrm{w}$ poszukiwaniu mieszkania, pracy, zagospodarowania się w nowym miejscu, a w konsekwencji łatwiejsze zbiorowe zmierzenie się z problemami - prowadziło to do tworzenia i zacieśniania więzi oraz osiedlania się blisko swoich ziomków. Można to było zaobserwować w wielu enklawach migrantów, m.in. przybyłych $\mathrm{w}$ latach dziewięćdziesiątych migranci z byłego Związu Radzieckiego zasiedlili wyraźnie wyodrębnioną część Berlina ${ }^{10}$, w enklawach chińskich powstajacych w wielu krajach europejskich i Stanach Zjednoczonych, enklawach wietnamskich w Polsce, czy enklawach specyficznej jednostki etnicznej określanej mianem franco-maghrébins, obejmującej imigrantów pochodzących z Algierii, Maroka i Tunezji, wywodzących się z byłych północnoafrykańskich kolonii francuskich, których łączy pochodzenie, religia (islam), znajomość języków (francuskiego i arabskiego) oraz świadomość wspólnych losów z czasów, gdy ich państwa stanowiły francuskie kolonie ${ }^{11}$.

Dla kolejnych fal migrantów przyjęcie przez bliską etnicznie społeczność oferujacca pomoc w zagospodarowaniu, a niejednokrotnie pracę w nowym i nieznanym kraju, jest udogodnieniem skłaniającym do przynależności. Szczególnie jest to widoczne w migracjach łańcuchowych, przybywaniu kolejnych członków rodzin, sasiadów, mieszkańców regionu poprzedniego miejsca zamieszkania. Niekiedy tworzy się sieć przestrzennych i funkcjonalnych powiązań między kolejnymi falami migrantów. Przykładowo powstające społeczności migrantów z krajów Maghrebu rozrastały się m.in. z powodu „ściagania” całych rodzin pochodzenia, braci, sióstr i dalszych krewnych, którzy zamieszkiwali w sasiedztwie. „W konsekwencji nierzadko powstawały na terenie europejskim odłamy poszczególnych rodów lub segmentów plemiennych. Ich członkowie, powiązani skomplikowanymi więzami krwi i relacji ekonomicznych, zamieszkują wspólnie całe ulice lub kwartały. Takie zwarte, krewniacze jednostki osadnicze tworzą niekiedy jądro większych dzielnic zamieszkałych przez mniejszość maghrebijską" ${ }^{2}$.

Dla migrantów przyjmowanych przez społeczności, do których należą krewni, przyjaciele lub ziomkowie za granica, adaptacja do nowych warunków staje się bardziej przystosowaniem do życia w enklawie niż w nowym społeczeństwie. Jest zrozumiałe, że dla wielu migrantów jest to łatwiejsze rozwiązanie.

${ }^{9}$ Por. R. Vorbich, Muzułmanie z Maghrebu w Europie Zachodniej, „Sprawy Narodowościowe”, Seria nowa, t. 4, 1955, z. 1 (6), s. 110.

${ }_{10}$ Por. A. Kapphan, Russian Entrepreneurs in Berlin. The Role of Ethnicity and Opportunity Structures. Referat powielony na konferencje „Ethnicity and Economy in Post-Socialist Space”, Sankt Petersburg 1999, 9-12 września; R. Suchocka, op. cit.

${ }^{11}$ R. Vorbich, op. cit., s. 98.

12 Ibidem, s. 111. 
W dużym stopniu o miejscu osiedlenia migrantów decyduje dostęp do tanich mieszkań, znajdujących się w opuszczonych przez zamożniejszych mieszkańców częściach miasta. Bliskość przestrzenna rodzi bliskość społeczną i wytwarza sprzyjające warunki do powstania enklawy w sensie społecznym. Jest także odwrotnie - społeczny wymiar enklawy, bliskość kulturowa jej członków wyzwala wolę przebywania wśród swoich i wytwarza sprzyjające warunki do bliskości przestrzennej. Dzieje się tak zarówno wtedy, gdy migranci zajmuja opustoszałe dzielnice miast, jak i wtedy, gdy mieszkaja w miejscach o innym przeznaczeniu, jak to czynili tadżyccy migranci na targowiskach Petersbur$\mathrm{ga}^{13}$. Bliskość terytorialna sprzyja nasileniu interakcji, a one - wzajemnej sympatii.

Żyjąc razem migranci zyskują względną łatwość życia i uczestnictwa, brak konieczności pokonywania barier kulturowych i edukacyjnych, pomoc ze strony innych migrantów, potrzebna zwłaszcza na początku pobytu. Szczególnie ważne jest poczucie przynależności do wspólnoty i przekonanie, że enklawa zapewnia poczucie bezpieczeństwa.

Enklawa staje się azylem dla osób, które z różnych powodów podjęły decyzję o migracji, lecz nie cechuje ich mobilność rozumiana jako pewna postawa życiowa, oznaczajaca łatwość przystosowywania się do zmian i nowych warunków. Życie wśród swoich utrwala nabyta wcześniej walencję kulturowa ${ }^{14}$ i pojedyncze identyfikacje narodowościowe z grupa pochodzenia. Rodzi się lub wzmacnia poczucie braterstwa, przywiązanie i sympatia do innych członków, które wzmacniane jest przez fakt, że enklawa zapewnia wsparcie społeczne w sytuacjach zagrażających. Nie tylko wspólna kultura i wspólnota losów dziejowych przodków, lecz także wspólnota losów migracyjnych i podobieństwo położenia w kraju osiedlenia, konieczność zmierzenia się z podobnymi problemami, przyczyniają się do wytwarzania silnych więzi. Wzajemna przydatność jednostek stwarza obszary wzajemnej zależności.

Wobec trudów życia w nowym społeczeństwie, w sytuacji podejmowania kontaktów z członkami przyjmującego społeczeństwa, np. zawodowych, ważna jest funkcja kompensacyjna, jaką pełni enklawa. Staje się ona mikroświatem, jedyną lub najważniejszą grupą odniesienia, z jej hierarchiami wartości, obowiązującymi normami i obowiązującymi wzorami kultury, wyznaczającą standardy oceny siebie i innych.

Specyficzną kategorią enklaw są te, które zmierzają do zapewnienia ekonomicznej ich samowystarczalności. Jak zaznaczał Alejandro Portes - badania prowadzone w społecznościach imigranckich Stanów Zjednoczonych wskazywały na podejmowanie przez migrantów aktywności ekonomicznej mającej na celu zaspokojenie potrzeb społeczności imigranckiej. Przede wszystkim Żydzi, Chińczycy i Kubańczycy tworzyli w niektórych regionach kraju skoncentrowane przestrzennie enklawy ekonomiczne, w których znajdowali zatrudnienie członkowie ich grupy etnicznej. Właściciele firm zapewniali miejsca pracy kolejnym napływającym migrantom. Cechą charakterystyczną tych enklaw

\footnotetext{
${ }^{13}$ R. Suchocka, op. cit.

${ }^{14}$ Pojęcia „walencja” używam w znaczeniu nadanym mu przez Antoninę Kłoskowską; por. eadem, Kultury narodowe u korzeni, WN PWN, Warszawa 1995, s. 110-111.
} 
jest heterogeniczność zawodowa ${ }^{15}$. Podobne enklawy powstawały w wielu miastach europejskich tworzone przez Chińczyków w wyodrębnionych przestrzeniach miast, tzw. Chinatown, czy przez rosyjskojęzycznych migrantów z byłego Związku Radzieckiego, zamieszkujacych wydzieloną część Berlina, a także przez franco-maghrébins we Francji, którzy produkuja, prowadzą usługi i handlują nastawieni na potrzeby swoich ziomków ${ }^{16}$.

Innym rodzajem enklaw etnicznych są te, które zapewniają pracę swoim członkom, wypełniając nisze ekonomiczne w społeczeństwach przyjmujących; są one nastawione na zaspokojenie potrzeb członków społeczeństwa przyjmującego i koncentrują imigrantów w określonych zawodach. Na zjawisko powstawania homogenicznych zawodowo enklaw etnicznych zwracał uwagę m.in. innymi Roger Waldenger ${ }^{17}$. Przykładowo: Mozabici i Berberzy z Atlasu sa drobnymi sklepikarzami prowadzacymi épiceries. Sieć hurtowni i sklepów detalicznych prowadzonych przez członków jednego plemienia marokańskiego Amnel - znajduje się we Francji i Stanach Zjednoczonych ${ }^{18}$.

Nastawienie na zaspokojenie potrzeb zarówno rodowitych mieszkańców kraju przyjmującego, jak i grupy własnej jest charakterystyczne dla enklaw Wietnamczyków w Polsce. Wyniki badań wskazuja, że Wietnamczycy tworzą nisze etniczne, a ich aktywność ekonomiczna charakteryzuje przestrzenna i branżowa koncentracja, silna kooperacja wewnątrzgrupowa i odrębność ekonomiczna ${ }^{19}$. Na Stadionie Tysiąclecia w Warszawie w 2001 r. znajdowało się ponad 1000 stanowisk wietnamskich ${ }^{20}$, barów z kuchnią wietnamska, stoisk z tekstyliami i obuwiem, prowadzono sprzedaż prasy, literatury, filmów wideo, płyt, a także artykułów żywnościowych. Klienci z własnej grupy etnicznej mogli korzystać z centrali telefonicznej pozwalającej na połączenie z rodziną oraz doradztwa prawnego, salonów fryzjerskich i kosmetycznych, a także centrum hazardu, gdzie obstawiano mecze piłkarskie i pojedynki bokserskie ${ }^{21}$.

Obok handlu hurtowego i detalicznego drugim sektorem aktywności Wietnamczyków jest gastronomia oraz hotelarstwo, przy czym niektóre restauracje sa zarazem centrami kultury wietnamskiej. Specyfika aktywności zawodowej polega na tym, że przebiega w środowisku własnej grupy etnicznej i cechuje ją duży poziom zaufania i kooperacja. Większość respondentów prowadziła własną działalność gospodarczą.

${ }^{15}$ A. Portes, Modes of Structural Incorporation and Present Theories, w: M. M. Kritz, Ch. B. Keely, S. M. Tomasi (red.), Global Trends in Migration Theory and Research on International Population Movements, The Center of Migration Studies, New York 1981.

16 Por. R. Vorbich, op. cit., s. 111.

17 Por. R. Waldenger, The Making of Immigrant Niche, „International Migration Review” 27, 1994, nr 1 .

18 Por. R. Vorbich, op. cit., s. 110.

19 Por. A. Fihel, A. Górny, P. Kaczmarczyk, Rynek pracy a integracja cudzoziemców z Ukrainy posiadajacych zezwolenie na osiedlenie się w Polsce, w: A. Grzymała-Kazłowska (red.), Między jednościa a wielościa. Integracja odmiennych grup $i$ kategorii imigrantów $w$ Polsce, Ośrodek Badań nad Migracjami, WNE UW, Warszawa 2008, www.migracje.uw.edu.pl/download/publikacja/658.

${ }^{20}$ Por. A. Grzymała-Kazłowska, Migranci z krajów mniej rozwiniętych gospodarczo niż Polska: przypadek Wietnamczyków, w: J. Grzelak, T. Zarycki (red.), Społeczna mapa Warszawy, Scholar, Warszawa 2004.

21 Por. A. Fihel et al., op. cit., s. 58-59. 
Wietnamczycy oferują także usługi dla firm, głównie wietnamskich, takie jak: księgowość, obsługa recepcyjna, różnego rodzaju pośrednictwo ułatwiające funkcjonowanie wietnamskich przedsiębiorstw, „inna aktywność zarobkowa niż handel czy gastronomia związana jest głównie z usługami dla własnej grupy etnicznej bądź opiera się na kapitale tejże grupy"22. Emigranci z Wietnamu osiadli w Polsce odgrywają ważną rolę w procesach adaptacji zawodowej nowo przybyłych migrantów - udzielają pomocy i oferują pracę.

Enklawy etniczne są najczęściej grupami ekskluzywnymi, wyłączającymi innych, ale też same stwarzaja podstawy społecznego wykluczania własnych członków ze społeczeństwa kraju przyjmującego. Istnieje szereg możliwych obszarów wykluczenia społecznego, rozumianego jako pozbawienie możliwości pełnego uczestnictwa w społeczeństwie. Anthony Giddens traktuje wykluczenie jako antynomię dla przynależności i wyróżnia wykluczenie ekonomiczne, polityczne i kulturowe ${ }^{23}$. Mając na myśli wykluczenie na ogół ma się na uwadze czynniki pozbawiające szans, które ma większość ludzi w społeczeństwie, aczkolwiek niekiedy zwraca się także uwagę na dobrowolną izolację i świadomy brak uczestnictwa ${ }^{24}$.

Konsekwencją szczególnie szkodliwą dla społeczeństw, w których powstają enklawy osób odmiennych etnicznie, może być wykluczenie społeczne członków enklawy, a właściwie samowykluczenie, pozbawiające możliwości pełnego uczestnictwa w życiu społeczeństwa kraju przyjmującego. Może to dotyczyć niemal wszystkich lub wybranych aspektów życia społecznego, wyłączywszy życie w enklawie.

Pojęcie samowykluczenia nie w pełni oddaje istotę zjawiska - nie jest to bowiem najczęściej wybór przynależących do enklawy pojedynczych jednostek, lecz wykluczanie przez fakt przynależności do enklawy, a właściwie - koszt, jaki ponosi jednostka za luksus przynależności. Szczególnie jest to widoczne w kolejnych pokoleniach migrantów.

Wykluczenie ekonomiczne obejmuje zarówno niemożność uczestnictwa lub pełnego uczestnictwa w rynku pracy, jak i konsumpcję ${ }^{25}$. Niemożność uczestnictwa, bezrobocie może wynikać z braku kwalifikacji, odpowiedniego wykształcenia pozwalającego znaleźć zatrudnienie. Niepełne uczestnictwo oznacza ograniczenie możliwości wykonywania pracy i zawodów przynoszących wyższe dochody, swobodne korzystanie z szerszego rynku pracy. Tak dzieje się w tych enklawach, których członkowie wypełniają nisze ekonomiczne społeczeństw przyjmujacych, wykonując zawody zapewniające egzystencję (np. handlarzy na targowiskach, tragarzy) czy świadczących drobne usługi (np. naprawiajacych obuwie, wykonujących prace w budownictwie itp.). Równocześnie są wykluczeni, a raczej sami się pozbawiają dostępu do innych możliwości oferowanych przez szerszy rynek pracy. Szczególna rola przypada tu

\footnotetext{
${ }^{22}$ A. Grzymała-Kazłowska, R. Stefańska, M. Szulecka, Podobieństwa i różnice w integracji imigrantów o różnym statusie prawnym, w: A. Grzymała-Kazłowska (red.), op. cit., s. 101-102.

${ }^{23}$ Por. A. Giddens, Socjologia, WN PWN, Warszawa 2006, s. 346-347.

${ }_{24}$ Anthony Giddens wskazywał na tzw. wykluczenie na szczycie najzamożniejszych członków społeczeństwa. Ibidem, s. 350.

25 Ibidem, s. 347.
} 
przypisaniu do określonych zawodów czy zajęć, przekazywaniu ich z pokolenia na pokolenie.

Otrzymanie pracy po przyjeździe do nowego kraju dzięki innym członkom enklawy rodzi zobowiązania i poczucie lojalności, co utrudnia odejście do innych zajęć, a tym samym awans w społeczeństwie przyjmujacym. Potwierdzają tę tezę wyniki badań migrantów z Wietnamu. Imigranci podejmowali zatrudnienie przeważnie w niszy etnicznej i byli uzależnieni od migrantów zadomowionych w Polsce. Zmuszeni byli wykonywać prace wskazane przez pracodawców, ułatwiających nielegalnym migrantom przyjazd do Polski ${ }^{26}$. Podobnie jest w tych enklawach, które ciążą do względnej samowystarczalności, stwarzając miejsca pracy, która ma na celu zaspokojenie potrzeb konsumpcyjnych członków enklawy.

Drugi z wymiarów wykluczenia ekonomicznego, który dotyczy konsumpcji, wiąże się zarówno z obiektywnymi możliwościami korzystania z oferowanych na rynku produktów, jak i własnymi wyborami migrantów. Ograniczenie czy wykluczenie z konsumpcji wynika zatem nie tylko z możliwego faktycznego lub względnego ubóstwa członków niektórych enklaw, lecz także z obowiązujących i kulturowo wyznaczonych wzorów konsumpcji. Niejednokrotnie też specyficzne potrzeby konsumpcyjne zostają zaspokojone w ramach enklawy i nie skłaniają do poszukiwań poza nią.

Z kolei samowykluczenie kulturowe obejmuje przede wszystkim brak pełnego uczestnictwa w szerszej kulturze, ale także brak możliwości współtworzenia tej kultury. Po pierwsze elementy kapitału kulturowego, do których należy znajomość języka, szerzej - kompetencje kulturowe, a także wykształcenie, należy odnosić relatywnie do określonych grup i społeczeństw, do określonej przestrzeni kulturowej. To, co stanowi kapitał kulturowy w jednych grupach, w innych - nie tylko może nie być kapitałem, może nawet być jego antynomią: „antykapitałem” (w tym sensie, że dopiero pozbycie się go, co wymaga dużego wysiłku ze strony migrantów, wytwarza możliwość wytworzenia nowego kapitału).

Te różnice pomiędzy kapitałami kulturowymi charakteryzującymi z jednej strony imigrantów, a z drugiej - społeczeństwo przyjmujace moga przyczyniać się też do negowania i odpychania przez członków enklaw kultury dominującej w przyjmującym społeczeństwie. Przykładowo: silna identyfikacja religijna członków mniejszości islamskiej we Francji prowadzi do samowykluczenia z kultury państwa goszczącego z powodu braku zgody tej społeczności na uczestnictwo w kulturze, której wartości są odrzucane. „Tożsamość etniczno-narodowa odwołuje się do krajów pochodzenia, co powoduje z kolei nieunikniony separatyzm od »francuskości« i zamknięcie tych wspólnot w społecznych gettach" ${ }^{27}$. W tym kontekście należy też postrzegać znaczenie i rolę kapitału migracyjnego, który z jednej strony likwiduje bariery przystosowawcze, lecz z drugiej wzmacnia i wytwarza więzi, które konstytuując enklawę, mogą okazać się przeszkodą w integracji ze społeczeństwem przyjmujacym.

${ }_{26}$ Por. K. Głąicka, T. Halik, A. Sawicka, Studia nad przerzutem migrantów, Prace Migracyjne, ISS 23, UW URL, Warszawa 1999, http://www.migracje.uw.edu.pl/obm/pix/023.pdf.

27 W. J. Burszta, op. cit., s. 132. 
Przynależność do enklawy jest obroną przed wykorzenieniem, pozwala na kultywowanie tradycji ojczystych. Stwarza możliwości uczestnictwa w kulturze, ponieważ zapewnia dostęp do literatury, muzyki, przedmiotów służących do ozdabiania domostw charakterystycznych dla rodzimej kultury, jak to ma miejsce np. w enklawie rosyjskojęzycznych migrantów w Berlinie, migrantów chińskich, wietnamskich, a także pochodzacych z krajów Maghrebu, tworzących w wielu miastach europejskich czy amerykańskich własne dzielnice.

Jeśli jednocześnie członkowie enklawy znajdują zatrudnienie w enklawie, a praca związana jest z zapewnieniem potrzeb ziomków, nie ma powodu do nauki języka kraju przyjmującego. Nawet w sytuacji gdy aktywność ekonomiczna członków enklawy związana jest z kontaktem z ludnością kraju przyjmującego, znajomość języka ograniczona jest często wyłącznie do kompetencji niezbędnych, by zapewnić porozumienie w sferze zawodowej. Z kolei brak wystarczajacych kompetencji kulturowych, nie tylko językowych w kraju przyjmującym ogranicza dostęp do kultury kraju przyjmującego.

Enklawy, które powstawały na skutek migracji łańcuchowych i strumieni migracji, składają się z osób przybyłych z jednego regionu czy miejscowości. Niejednokrotnie np. wskazywano, charakteryzując polską migrację, że do określonych krajów i miejsc w tych krajach napływali mieszkańcy z tych samych regionów, jak np. z Podhala do Stanów Zjednoczonych, Śląska Opolskiego do Niemiec ${ }^{28}$. Podobnie charakteryzowano emigrację z krajów Maghre$\mathrm{bu}^{29}$. Powstające małe ojczyzny wspierają się na kulturze regionalnej krajów wysyłających - powielają i utrwalają wzorce tej kultury także w kolejnych pokoleniach. Prowadzi to do przenoszenia lokalnych, ludowych kultur, kultywowania i utrwalania tych elementów, które odwołują się przede wszystkim do doświadczeń z przeszłości, często ograniczonych do przestrzeni regionalnej, odpornych na zmiany dokonujące się w kulturze krajów macierzystych. Te „skansenowe” kultury lokują się w miejskim etnokrajobrazie. Sentyment związany $\mathrm{z}$ miejscem urodzenia, nawyki wyniesione $\mathrm{z}$ domu rodzinnego, zwyczaje i obyczaje, „wytwarzania tradycji” sprawiaja, że sa przekazywane i utrwalane w kolejnych pokoleniach, jakby wbrew oddziaływaniom i możliwościom oferowanym przez współczesne technologie informacyjne, pozwalające opuścić świat wspólnoty. Korzystanie m.in. z sieci internetowej, a także telefonów komórkowych ułatwia częste kontaktowanie się i zacieśnianie więzi z rodzina, przyjaciółmi i znajomymi w kraju, co raczej umacnia poczucie odrębności kulturowej w kraju osiedlenia.

Kolejnym obszarem wykluczenia imigrantów jest polityka. W wypadku członków wielu enklaw wynika ono z niechęci do uczestnictwa w tej sferze, braku zainteresowania problemami kraju przyjmującego, a także braku możliwości publicznego artykułowania swoich potrzeb, nie ze względu na dyskryminujace praktyki władzy, lecz niemoc spowodowaną wykluczeniem kulturowym lub ekonomicznym.

Niepokojącym zjawiskiem jest powstawanie spirali wykluczenia społecznego, np. niepodejmowanie edukacji niezbędnej do pełnego uczestnictwa

${ }^{28}$ Por. J. Plewko, Migracje poakcesyjne z Polski (2004-2008). Społeczne aspekty wyjazdów, w: G. Koszałka et al. (red.), op. cit., s. 25.

${ }^{29}$ Por. R. Vorbich, op. cit. 
w rynku pracy, w dużym stopniu spowodowane bariera językowa, pozbawia szans na satysfakcjonujace zatrudnienie. Wprawdzie enklawy, które wypełniaja nisze ekonomiczne w krajach przyjmujacych, zapewniaja pracę swym członkom, jednakże równocześnie skazują na ograniczenie możliwości wyboru drogi zawodowej do jednej lub kilku. Tym samym ograniczają możliwość awansu społecznego dostępnego poza enklawa. Utrudniaja, a nawet czynia zupełnie niemożliwym dostęp do wyższych społecznych pozycji, wykluczaja z życia społecznego poza enklawą.

Samowykluczanie występuje jako rezultat dość banalnego faktu, że łatwiej być Swoim niż Innym, Obcym. Niestety - im silniejsza jest więź wiążąca z zamkniętą enklawą i poczucie solidarności z jej członkami, tym mniejsza szansa na integrację z Innymi. W tej sytuacji enklawa uruchamia spiralę społecznego samowykluczenia.

Dodatkowym aspektem wykluczającej mocy enklawy jest poziom jej instytucjonalnej kompletności. Według Raymonda Bretona im jest on wyższy, tzn. w społecznościach imigrantów obok nieformalnych więzów rodzinnych, przyjacielskich i sasiedzkich powstaja formalne i nieformalne organizacje (jak np. pomocowe, ekonomiczne, handlowe, religijne, edukacyjne, polityczne, profesjonalne, hobbystyczne i informacyjne), tym większa spójność w ramach grupy własnej i niższa częstotliwość kontaktów zewnętrznych ${ }^{30}$.

Większa otwartość cechuje często narody pochodzenia migrantów niż członków enklaw. Aczkolwiek nie ma danych statystycznych wskazujących na liczbę małżeństw mieszanych zawieranych przez migrantów z ludnościa w krajach osiedlenia, jednakże na ogół członkowie enklaw zawierają związki małżeńskie z reprezentantami grupy własnej.

Jak wskazywał Pierre Bourdieu, kapitał kulturowy jest jedna z ukrytych barier na drodze awansu społecznego w danym społeczeństwie ${ }^{31}$. Mając na uwadze jego ograniczenie do określonej przestrzeni kulturowej, dodatkowego znaczenia nabiera to w relacji świata enklawy ze światem zewnętrznym. Odmienność zasobów niezbędnych do utrzymywania enklawy i przez nią wytwarzanych od tych, które są podstawą zajmowania określonych pozycji w społeczeństwie kraju przyjmującego, skazuje na niepowodzenie próby zmiany pozycji w hierarchii społecznej poza enklawa. Dodatkowo - im silniejsze więzi spajają migrantów, tzn. im większy jest kapitał społeczny, tym słabsze możliwości awansu w społeczeństwie poza enklawa. Jest on możliwy, po pierwsze, w sytuacji, gdy obok kapitału wiążącego występuje kapitał pomostowy (w rozumieniu nadanym mu przez Roberta D. Putnama) niezbędny, by podejmować współpracę z osobami nieznanymi ${ }^{32}$, po drugie, gdy zasoby kapitału wiążącego nie oznaczają zbyt silnych więzi między członkami enklawy migrantów. Te

${ }^{30}$ Por. R. Breton, Institutional Completeness of Ethnic Communities and Personal Relations of Immigrants, „American Journal of Sociology” 70, 1964, nr 2, s. 193-205.

${ }^{31}$ P. Bourdieu, The Forms of Capital, w: J. G. Richardson (red.), Handbook of Theory and Research for Sociology of Education, Greenwood Press, New York 1986, s. 241-258, oraz P. Bourdieu, J. C. Passeron, Reprodukcja. Elementy teorii systemu nauczania, Wydawnictwo Naukowe PWN, Warszawa 2006.

${ }^{32}$ R. D. Putnam, R. Leonardi, R. Naretti, Demokracja w działaniu: tradycje obywatelskie we współczesnych Włoszech, Znak, Kraków 1995. 
zbyt silne więzi, ograniczające swobodę osób przynależących, mogą prowadzić do powstawania ,antykapitału” i tworzyć podstawy wykluczania, m.in. przez zmuszanie do zbyt dużych ofiar na rzecz wspólnoty prowadzących do ograniczania własnego rozwoju jednostek, ograniczanie swobody działania, wywieranie presji na zaniżenie aspiracji i standardów społecznych, utrudnianie awansu, który łączy się ze zmniejszeniem zależności od grupy lub odejściem od jej kultury ${ }^{33}$. Jest to przeważnie związane z kwestią lojalności wobec członków enklawy i dokonywanym wyborem pomiędzy lojalnością wobec społeczności migrantów a społeczeństwem przyjmujacym.

Na ogół występowanie tzw. kapitału migracyjnego i będących jego nośnikami sieci migracyjnych ${ }^{34}$ (wiążących jednostki i rodziny w dwóch lub więcej krajach), na który to kapitał składają się zasoby wiedzy dostępnej dla migrantów, ułatwiajacej przystosowanie do życia w nowym społeczeństwie, kapitał kulturowy i ekonomiczny, oraz powiązania z posiadaczami tych zasobów, możliwość korzystania z ich pomocy (zwłaszcza w znalezieniu pracy i mieszkania), jest oceniane pozytywnie, jako gwarancja adaptacji przybyszów w kraju osiedlenia. Należy jednak mieć na uwadze jego drugie oblicze: jest kapitałem pomostowym, łączącym społeczności dawnych, nowych i potencjalnych migrantów. Jednakże jego cechą jest skłonność do koncentracji w kraju przyjmujaccym, sprzyjajaca tworzeniu enklaw. Adaptacja w nowym środowisku oznacza wówczas, jak wskazywano wcześniej, bardziej przystosowanie do życia w enklawie niż poza nią.

Kapitał migracyjny niekoniecznie wykazuje zdolność przekształcania się w inne formy kapitału występujące w kraju przyjmującym, może ułatwiać przystosowanie na początku pobytu, minimalizować koszty ekonomiczne i społeczne ponoszone przez jednostki zmieniajace miejsce osiedlenia, zapewniać poczucie bezpieczeństwa, lecz równocześnie wiążąc z enklawą więzami zobowiązania, stawać się przeszkodą awansu w społeczeństwie przyjmującym. Wygoda płynąca z przynależności utrudnia „wyplątanie się z sieci”.

Opisujac sieci migracyjne, Douglas Gurak i Fe Caces wskazali m.in. na takie ich funkcje, jak: ochrona migrantów przed utrudnieniami podczas migracji, oddzielenie migrantów od społeczeństwa przyjmującego i podtrzymywanie ich związków ze społecznością wysyłajaca, wpływanie na integrację w społeczeństwie przyjmującym (m.in. służą jako kanały informacji i struktury normatywne $)^{35}$. Należy zwrócić uwagę, że nadmierna ochrona migrantów i oddzielanie ich od społeczeństwa przyjmującego, a także niektóre struktury normatywne mogą okazać się przeszkodą w integracji społecznej. Ostateczniewarto brać pod uwage jakość kapitału migracyjnego, to w jakim stopniu staje się kapitałem pomostowym, łączącym społeczności różnych kultur, a w jakim

${ }^{33}$ A. Portes, Social Capital: Its Origins and Applications in Modern Sociology, „Annual Review of Sociology" 24, 1998, s. 1-24.

${ }^{34}$ A. Górny, D. Stola, Akumulacja i wykorzystanie migracyjnego kapitatu spotecznego, w: E. Jaźwińska M. Okólski (red.), Ludzie na huśtawce. Migracje między peryferiami Polski i Zachodu, Scholar, Warszawa 2001.

${ }^{35}$ D. T. Gurak, F. Caces, Migration Networks and the Shaping of Migration Systems, w: M. M. Kritz, L. L. Lim, H. Zlotnik (red.), International Migration Systems, Clarendon Press, Oxford 1992, s. 150-176. 
kapitałem - łącznikiem pomiędzy enklawą a społecznością wysyłającą migrantów.

Warunkiem skorzystania z możliwości oferowanych przez przyjmujące społeczeństwo jest możliwość przekształcania, konwersji kapitału, którym dysponują członkowie enklawy, w inne formy kapitału poza nią. Jeśli przyjąć za Pierre'em Bourdieu, że u podstaw społecznej stratyfikacji leży łączny kapitał jednostki, na który składa się kapitał ekonomiczny, kulturowy (obejmujący wiedzę, wykształcenie, predyspozycje sprzyjające opanowaniu dziedzictwa kulturowego) oraz społeczny, a także - kapitał władzy ${ }^{36}$, łatwo zauważyć, że najłatwiejsze jest wykorzystanie kapitału ekonomicznego jako podstawy awansu społecznego poza enklawą. Uprzedmiotowiona postać kapitału kulturowego, etniczne produkty kultury pochodzenia - mogą być produktem możliwym do zaoferowania w społeczeństwie przyjmujacym.

W analizach kapitału migracyjnego, zwraca się przede wszystkim uwagę na jego aspekt społeczny, sieci powiązań międzyludzkich oraz powiązań z wspomagającymi instytucjami. Nie mniej ważna jest jednak jakość kapitału kulturowego, w tym poziomu i rodzaju wykształcenia, kwalifikacji, często powiązanych z nim kompetencji kulturowych niezbędnych w kraju przyjmującym, od znajomości języka poczynając. Podobnie dysponowanie kapitałem ekonomicznym ułatwia start w nowym środowisku, zapewnienie mieszkania i godziwych warunków życia w początkowym okresie pobytu, a także założenie własnego przedsiębiorstwa. Te rodzaje zasobów mogą uwalniać od uzależnienia od enklawy, zmniejszając znaczenie kapitału społecznego. Jednakże złożone relacje pomiędzy różnymi rodzajami kapitału sprawiają że niejednokrotnie subiektywnie odczuwane korzyści z przynależności do sieci, zwłaszcza obejmujących członków rodziny czy przyjaciół, względy lojalności oraz zobowiązań wobec nich nie pozwalaja w pełni skorzystać z zasobów, które pozwalaja na skorzystanie z możliwości oferowanych przez kraj osiedlenia. Potwierdzają to m.in. innymi obserwacje enklaw rosyjskojęzycznej ludności w Berlinie czy Wietnamczyków w Polsce, również w kolejnym pokoleniu. Osoby mające wyższe wykształcenie, także uzyskane w kraju przyjmującym, często decydują się na prowadzenie własnej działalności, której celem jest zaspokojenie potrzeb ziomków, i świadczenie usług dla członków enklawy (np. ich obsługa prawna).

Brak zdolności lub możliwości przekształcania się kapitału, którym dysponują migranci, sprawia, że na zewnątrz enklawy staje się on kapitałem zamrożonym, a nawet zmarnowanym. Staje się „antykapitałem” w tym sensie, że nie pozwala na wytwarzanie wartości dodatkowej, nie przynosi zysku, nie wykazuje zdolności do konwersji. Między innymi kapitał społeczny konstytuujący enklawę może nawet, zgodnie z tezą Putnama, „poprzez tworzenie silnej lojalności wewnątrzkulturowej [...] równocześnie wytwarzać silny antagonizm zewnątrzkulturowy" ${ }^{37}$. Kapitał pomostowy należy zatem rozumieć jako zaufanie i umiejętność współpracy z osobami na zewnątrz enklawy, budowanie

${ }^{36}$ P. Bourdieu, The Forms..., passim.

${ }^{37}$ R. D. Putnam, Samotna gra $w$ kręgle. Upadek i odrodzenie wspólnot lokalnych $w$ Stanach Zjednoczonych, Wydawnictwa Akademickie i Profesjonalne, Warszawa 2008, s. 41-42. 
sieci powiązań pomiędzy nią a zewnętrznym środowiskiem, w odróżnieniu od spajającego enklawy etniczne powinien być łączący. Niezbędne jest tu jednak zaangażowanie i wola obu stron, zarówno społeczności migrantów, otwartych na innych, pomimo dzielących ich różnic oraz odmiennych wartości, jak i społeczności kraju przyjmującego oraz państwa gwarantującego bezpieczeństwo migrantów i ich prawa, a więc tworzacego podstawy zaufania i godnego zaufania. Zostaja wtedy spełnione warunki społecznej partycypacji, zgodnie z teza Putnama, że zaufanie jest konieczne, by ludzie ze sobą współdziałali i partycypowali w grupach społeczeństwa obywatelskiego, przy czym oba te wymiary składaja się na kapitał społeczny. Sa to takie cechy „organizacji społeczeństwa, jak zaufanie, normy i powiązania, które mogą zwiększyć sprawność społeczeństwa ułatwiając skoordynowane działania"38.

Istnieją dwie grupy czynników konstytuujących enklawy etniczne: wewnętrzne, wyrażające wolę jej członków, oraz zewnętrzne, na ogół związane z polityką państw przyjmujących wobec migrantów. Paradoksalnie - zarówno zbyt „liberalna”, jak i dyskryminująca polityka sprzyja utrzymywaniu się enklaw. Związane jest to z pojmowaniem obywatelstwa, a zwłaszcza praktyka nie tylko zapewniania praw, lecz także egzekwowania obowiązków obywatelskich. Członków enklawy bardziej charakteryzuje lojalność wobec swoich niż obcych, czyli społeczeństwa i państwa przyjmującego. Stając się wspólnota, enklawa ogranicza wybory jednostek, które dokonują się przy jej pomocy.

W sytuacji otwartości krajów przyjmujacych, rosnącej wielokulturowości społeczeństw, globalnej implozji, istnienie enklaw etnicznych może stanowić zagrożenie dla integracji tych społeczeństw w różnych jej wymiarach. Wyrazem tego jest coraz częściej widoczna przestrzeń miejska złożona z mikrokosmosów „małych ojczyzn” tworzonych przez zbiorowości migrantów. Wyrazem globalnej implozji i peryferyzacji centrum sa takie zjawiska, jak „karaibizacja” Nowego Jorku, „latynizacja” San Francisco, wspólnoty Syngalezów w miastach Włoch, Algierczyków we Francji, Turków w Niemczech ${ }^{39}$. Segregacja, zwłaszcza przestrzeni miejskiej, za która „ukrywają się” segregacja społeczna i społeczne nierówności, jest zagrożeniem dla integralności współczesnych wielokulturowych społeczeństw.

Takie oblicze wielokulturowości, które ukazuje bariery kontaktu między kulturami i dyskredytuje to, co cenne dla każdej z nich, a co wynika z możliwości przenikania kultur, nieuchronnie rodzi pytanie o społeczne skutki i wizję przyszłości. Z jednej strony coraz częściej widoczna jest otwartość społeczeństw na migrantów, zwłaszcza tych, które borykają się z problemami demograficznymi, z drugiej - skłonność do tworzenia enklaw przez imigrantów.

Jak wskazują niektórzy, realizowanie zasady swobodnego przepływu osób w ramach krajów Unii Europejskiej i europejskie obywatelstwo zaowocowały powstaniem takich postaw osób migrujacych, które charakteryzuje brak poczucia bycia imigrantami, a w konsekwencji - nie podejmują one żadnych kroków zmierzających do integracji ze społeczeństwem przyjmujacym. Wyrazem

${ }^{38}$ R. D. Putnam, R. Leonardi, R. Naretti, op. cit., s. 258.

${ }^{39}$ W. J. Burszta, Konteksty etniczności, „Sprawy Narodowościowe”, Seria nowa, t. 6, 1997, z. 1 (10), s. 161. 
tego jest m.in. swoiste rozumienie własnego obywatelstwa jako ograniczającego się do korzystania z praw bez obowiązków, jako równouprawniającego, lecz nieprowadzącego do żadnych wyrzeczeń.

Przegląd enklaw tworzonych przez migrantów w państwach europejskich i Stanach Zjednoczonych ukazuje ich dużą różnorodność, która wynika z usytuowania na kontinuum w zależności od stopnia ich otwartości, przy czym otwartość należy utożsamiać z akceptacją i wspieraniem swoich członków w osiaganiu celów edukacyjnych czy ekonomicznych (jak np. zapewniających dostęp do szerszego rynku pracy poza enklawa), jako stwarzanie możliwości pełnego uczestnictwa w życiu społecznym i awansu społecznego w kraju przyjmującym. Niejednokrotnie łączy się to z oddzieleniem sfery życia prywatnego, w której kultywowane są tradycje kraju przodków, język ojczysty i wzory kultury, oraz sfery życia publicznego, która wymaga znajomości kultury kraju pobytu. Utrzymywanie się stanu równowagi między nimi może prowadzić do biwalencji kulturowej imigrantów, a także ich podwójnych identyfikacji.

$$
* * *
$$

Przyzwolenie na wielokulturowość już dawno nie oznacza w państwach demokratycznych presji asymilacyjnej. Nawiasem mówiąc, z tego właśnie powodu Francis Fukuyama obawia się zagrożenia dla „powszechnych”, w tym amerykańskiej, tożsamości, które niesie „miniaturyzacja moralna” i wiara w relatywizm moralny ${ }^{40}$ Różnorodność etniczna współczesnych społeczeństw, do których przybywali migranci, jest faktem, podobnie jak mozaikowy krajobraz miast, w których powstają i egzystują enklawy etniczne, zagrażające integralności społeczeństw przyjmujących, ale też dysponujące kapitałem, który może być z powodzeniem wykorzystany poza nimi. Wydaje się, że skuteczną drogą sprzyjającą integracji jest dążenie do sytuacji, w której członkowie enklaw mają zapewniony dostęp do dóbr cenionych zarówno w ich społecznościach, jak i poza nimi. Enklawa spełnia pozytywną rolę, gdy pełni funkcję kompensacyjną (niweluje negatywne skutki życia poza nia), lecz nie wykluczajaccą. Wytwarzają się wtedy warunki dla powstawania podwójnych identyfikacji i biwalencji kulturowej. Wymaga to jednak współdziałania obu stron w budowaniu kapitału pomostowego, przybyszów i społeczeństwa przyjmującego.

Aczkolwiek przedstawione rozważania dotyczą enklaw etnicznych, niektóre z wniosków mają charakter bardziej ogólny i można je odnosić także do innych enklaw społecznych. Dotyczy to m.in. wzajemnego wspomagania bliskości przestrzennej i społecznej w powstawaniu i utrzymywaniu enklawy, w którym każda z nich jest czynnikiem prowadzącym do powstania tej drugiej. Odnoszą się one także do zależności pomiędzy stopniem zamknięcia enklawy, a wykluczeniem społecznym z różnych obszarów życia poza enklawą. Im silniejsza jest więź łącząca członków enklawy, tym większe prawdopodobieństwo izolacji społecznej i samowykluczenia z życia społecznego poza nią.

${ }^{40}$ F. Fukuyama, op. cit., s. 254. 
Różne rodzaje kapitału: ekonomiczny, kulturowy czy społeczny występujące w enklawie nie stanowia automatycznie kapitału poza nią, a nawet mogą być „antykapitałem”, czyli takim wyposażeniem jednostek, które stanowi bariery pełnego uczestnictwa w społeczeństwie.

dr hab. Renata Suchocka

Profesor Uniwersytetu im. Adama Mickiewicza w Poznaniu

rsuchocka@wp.pl

TWO FACES OF IMMIGRANTS' LIFE IN AN ETHNIC ENCLAVE

Sum mary

This paper identifies the social impact and the pros and cons of immigrants' life in an ethnic enclave and analyses aspects that are conducive to integration with the host society, as well as those that obstruct members of the enclave to fully integrate. Concepts of social, cultural and migration capitals and the importance of migration networks in the adaptation of immigrants were taken into consideration and the study focused on the relationship between the impact of the enclave and the possibilities of social advancement in the host society. An attempt was also made to show the social effects of the pressure exerted by the enclave on areas of economic, cultural, political self-exclusion.

Integration with the host society is contingent upon the existence of a bridging capital and the building of networks connecting migrants with the external environment, consequently enabling their wider participation in society. 
Copyright of Journal of Law, Economics and Sociology is the property of Faculty of Law and Administration of Adam Mickiewicz University in Poznan and its content may not be copied or emailed to multiple sites or posted to a listserv without the copyright holder's express written permission. However, users may print, download, or email articles for individual use.

Właścicielem praw autorskich do „Ruchu Prawniczego, Ekonomicznego i Socjologicznego” jest Wydział Prawa i Administracji Uniwersytetu im. Adama Mickiewicza w Poznaniu. Zawartość czasopisma nie może być kopiowana, przesyłana do innych stron internetowych bądź zamieszczana na blogach bez pisemnej zgody wydawcy. Niemniej artykuły można drukować, kopiować lub przesyłać w formie elektronicznej na własny użytek. 